\title{
POTENSI CENDAWAN ENDOFIT PADA TANAMAN BINAHONG (Anredera cordifolia (Ten.) Steenis) UNTUK MENGENDALIKAN Botryodiplodia theobromae Pat. PENYEBAB MATI PUCUK PADA BIBIT JABON (Anthocephalus cadamba (Roxb.) Miq)
}

\author{
The Potency of Endophytic Fungi in Binahong (Anredera cordifolia (Ten.) Steenis) in
}

Controlling Botryodiplodia theobromae Pat. Causing Dieback Disease on Jabon

(Anthocephalus cadamba (Roxb.) Miq

Yunik Istikorini ${ }^{*}$

(Diterima Juni 2019/Disetujui Agustus 2019)

\begin{abstract}
Endophytic fungi provides potential advantages as biocontrol agents in the plant. Binahong (Anredera cordifolia) is a medicinal plant which can potentially overcome many kinds of diseases. The dieback disease is caused by Botryodiplodia theobromae Pat. that may lead the death of the host. The objective of this research was to analyze the potency of endophytic fungi from binahong leaves to control the fungus B. theobromae as causal agent of dieback disease on jabon (Anthocepalus cadamba). The isolates of endophytic fungi from binahong used were bnh1.1, bnh1.2, bnh1.3, bnh4.2, bnh4.5, bnh3.3 and bnh3.4. The antifungal effect of endophytic fungi againts colony growth of virulent $B$. theobromae were tested in vitro. The results showed that all endophytic fungus (7 isolates) inhibited the colony development of B. theobromae ranging from 28.52\%-52.22\%. Treatment with endophytic fungi bnh4.5 and bnh4.2 had protected jabon from virulent $B$. theobromae. It has been expressed by the delay of the incubation period and the decreasing of disease severity (respectively $33.34 \%$ and $40.84 \%$.
\end{abstract}

Key words: Anredera cordifolia, Botryodiplodia theobromae, disease incidence, endophytic fungi

\section{PENDAHULUAN}

Jabon (Anthocephalus cadamba (Roxb.) Miq) merupakan jenis pohon cepat tumbuh dan memiliki nilai ekonomi yang tinggi (Warisno dan Dahana 2011). Kayu jabon baik digunakan untuk pembuatan peti, papan tipis, korek api, pensil, vinir dan kayu lapis serta untuk pulp dan kertas (Wahyudi 2012). Jabon mempunyai banyak manfaat dan keunggulan. Oleh karena itu, jabon banyak dibudidayakan pada level pembibitan.

Salah satu kendala utama di pembibitan tanaman jabon adalah gangguan patogen penyebab penyakit tanaman yang dapat menimbulkan kematian bibit. Penyakit penting di pembibitan tanaman jabon antara lain, mati pucuk, bercak daun dan hawar daun. Berdasarkan hasil identifikasi Anggraeni dan Lelana (2011), penyakit bercak daun pada tanaman jabon putih disebabkan Colletotrichum sp. Penyakit hawar daun dan mati pucuk pada jabon putih berturut-turut disebabkan oleh Fusarium sp. dan Botryodiplodia sp. (Herliyana et al. 2012). Menurut Arshinta (2013), kejadian penyakit mati pucuk pada bibit jabon putih umur 3, 4, dan 5 bulan masing-masing sebesar $100 \%$, sedangkan keparahan penyakit mati pucuk berturut-turut adalah 61.42, dan $54 \%$.

\footnotetext{
${ }^{1}$ Departemen Silvikultur, Fakultas Kehutanan

IPB University

* Penulis Korespondensi

E-mail: yunik.istikorini@gmail.com
}

Menurut Anggraeni dan Lelana (2011), Botryodiplodia sp. dilaporkan sebagai patogen penyebab penyakit pada sejumlah tanaman kehutanan di Indonesia, antara lain menyebabkan bercak daun pada pulai (Alstonia sp.), merbau (Intsia bijuga Kuntze.), bakau (Rhizophora mucronata Lamk.), dan skubung (Macaranga gigantea Muell.), busuk akar pada meranti (Shorea sp.), bledok pada nyamplung (Calophyllum inophyllum Linn.), dan penyakit batang pada gaharu (Aquilaria malaccensis Lamk.). Begoude et al. (2009) lebih menjelaskan bahwa Botryosphaeriaceae mempunyai inang yang sangat luas mencakup gymnospermae, dan angiospermae. $B$. theobromae merupakan patogen yang menginfeksi inang melalui luka-luka mekanis seperti luka akibat pemangkasan atau serangga (Semangun 2007). Penelitian Aisah (2014) menunjukkan bahwa, bibit jabon putih umur 4 bulan dengan cara infeksi tanpa pelukaan batang yang diinokulasikan Botryodiplodia spp. mengalami gejala penyakit mati pucuk. Aisah (2014) melaporkan bahwa kejadian penyakit dan keparahan penyakit pada bibit jabon mencapai $100 \%$. Salah satu alternafif pengendalian yang dapat digunakan, yaitu menggunakan agen hayati yang lebih ramah lingkungan.

Cendawan endofit merupakan salah satu agensia hayati yang berpotensi untuk mengendalikan penyakit tanaman (Faeth 2002). Beberapa cendawan endofit mampu meningkatkan pertumbuhan dan ketahanan tanaman (Sinclair dan Cercaukas 1996). Cendawan 
endofit menghasilkan mikotoksin atau metabolit lain yang menyebabkan perubahan fisiologi dan biokimia inang (Clay 1988), sehingga keberadaan endofit dalam jaringan tanaman dapat berperan langsung dalam menghambat perkembangan patogen dalam tanaman (Niere 2002).

Isolasi cendawan endofit, antara lain dapat dilakukan pada tanaman obat binahong (Anredera cordifolia (Ten.). Mikrobia endofit dapat menghasilkan senyawa bioaktif yang karakternya mirip atau sama dengan senyawa yang diproduksi oleh tumbuhan inangnya. Senyawa bioaktif tersebut antara lain dapat dimanfaatkan sebagai antifungi, anti bakteri dan antivirus (Tan \& Zau (2000) dalam Radji (2005); Strobel et al.,2003). Perasan daun binahong diketahui dapat menghambat pertumbuhan bakteri Escherichia coli secara in vitro (Darsana, 2012). Potensi ini merupakan peluang yang sangat besar untuk mengisolasi cendawan endofit dari tanaman binahong. Bagian tanaman binahong yang biasa digunakan sebagai bahan obat adalah bagian daun. Hal ini merupakan peluang pemanfaatan endofit dari tanaman binahong untuk mengendalikan patogen pada tanaman. Penelitian ini bertujuan untuk menganalisis potensi cendawan endofit dari daun binahong ( $A$. cordifolia) sebagai agensia hayati yang mampu mengendalikan penyebab penyakit mati pucuk (B. theobromae) pada bibit jabon putih (A. cadamba).

\section{METODE PENELITIAN}

\section{Waktu dan Tempat}

Penelitian ini dilaksanakan pada bulan Februari sampai dengan bulan Juni 2017. Lokasi penelitian ini adalah di rumah kaca dan Laboratorium Patologi Hutan, Departemen Silvikultur Fakultas Kehutanan IPB.

\section{Prosedur Penelitian}

\section{Penyiapan Isolat Patogen dan Cendawan Endofit}

Isolat Botryodiplodia.theobromae patogen mati pucuk pada bibit jabon putih (A. cadamba) dan cendawan endofit diperoleh dari koleksi isolat Laboratorium Patologi Hutan, Fakultas Kehutanan IPB. Jenis cendawan endofit yang digunakan sebanyak tujuh isolat yaitu bnh1.1, bnh1.2, bnh1.3, bnh4.2, bnh4.5, bnh3.3 dan bnh3.4 yang berasal dari daun tanaman binahong (Anredera cordifolia). Perbanyakan isolat dilakukan dengan menggunakan media agar dektrosa kentang (ADK).

\section{Uji penghambatan cendawan endofit terhadap cendawan patogen secara in vitro \\ Pengujian dilakukan dengan menumbuhkan potongan koloni isolat cendawan endofit dengan $B$. theobromae (diameter $4 \mathrm{~mm}$ ) pada media ADK tersebut. Jarak antar isolat sebesar $5 \mathrm{~cm}$ dalam cawan petri (diameter $9 \mathrm{~cm}$ ). Perlakuan kontrol isolat B. theobromae ditanam pada media ADK tanpa cendawan endofit. Biakan diinkubasi selama 6 hari pada suhu ruang.}

Pengamatan dilakukan setiap hari dengan parameter yang diamati adalah pertumbuhan cendawan, lebar zona penghambatan, dan persentase penghambatan $(\mathrm{P})$. Lebar zona penghambatan adalah lebar zona antara kedua ujung koloni cendawan, diukur pada hari ke-5 setelah kedua koloni cendawan ditumbuhkan pada cawan petri. Persentase hambatan diukur setelah hari ke-6 dengan menggunakan rumus Singh et al. (2010):

$$
\mathrm{P}=\frac{(\mathrm{X}-\mathrm{Y})}{\mathrm{X}} \times 100 \%
$$

keterangan: $\mathrm{P}=$ persentase penghambatan $(\%)$

$\mathrm{X}=$ jari-jari koloni $B$. theobromae tanpa cendawan endofit (kontrol)

$\mathrm{Y}=$ jari-jari koloni $B$. theobromae yang tumbuh ke arah cendawan endofit

Uji penghambatan secara in vitro dilakukan menggunakan Rancangan Acak Lengkap. Setiap perlakuan dilakukan sebanyak 3 kali ulangan. Data daya hambat yang diperoleh dianalisis ragam dengan menggunakan program statistik SAS dan perbedaan nilai tengah daya hambat antar perlakuan diuji dengan uji jarak berganda Duncan pada taraf nyata $\alpha=0.05$.

\section{Uji in vivo cendawan endofit terhadap cendawan patogen}

Bibit jabon putih (A. cadamba) berumur 4 bulan ditanam di dalam pot berisi campuran tanah dan pupuk kandang (1:1). Inokulasi cendawan endofit dilakukan dengan cara penyiraman suspensi konidia cendawan endofit $5 \mathrm{~mL}\left(10^{5} \mathrm{konidia} / \mathrm{mL}\right)$ di dekat perakaran bibit jabon (A. cadamba). Bibit jabon putih (A. cadamba) diinokulasi dengan $B$. theobromae setelah 1 minggu penanaman. Inokulasi patogen dilakukan dengan menggunakan metode Yanti (2015) yang telah dimodifikasi, yakni dengan penempelan blok agar.

Batang jabon putih (A. cadamba) yang sehat dilukai dengan jarum suntik steril, kemudian blok agar yang mengandung $B$. theobromae (diambil menggunakan corkborer berdiameter $6 \mathrm{~mm}$ ) ditempelkan pada batang yang telah dilukai dan dilapisi dengan kapas lembab. Blok agar yang digunakan adalah kultur berumur 7 hari yang mengandung patogen. Batang jabon putih tersebut ditutup menggunakan aluminium foil untuk menjamin patogen tidak terlepas selama 14 hari pengamatan. Kelembaban kapas dijaga dengan memberikan beberapa tetes akuades steril setiap hari. Tanaman kontrol diinokulasi dengan blok agar tanpa isolat. Parameter yang diamati adalah masa inkubasi, kejadian dan keparahan penyakit yang disebabkan oleh $B$. theobromae pada bibit jabon putih.

1. Masa Inkubasi, yaitu waktu setelah inokulasi patogen $B$. theobromae sampai terlihatnya gejala penyakit, yang secara visual berupa bercak nekrotik berwarna coklat.

2. Kejadian penyakit $(\mathbf{K j P})$ pada bibit jabon putih $(A$. cadamba) dihitung menggunakan rumus sebagai berikut: 


$$
\mathrm{KjP}=\frac{\mathrm{a}}{\mathrm{N}} \times 100 \%
$$

keterangan:

$\mathrm{KjP}=$ kejadian penyakit $(\%)$

$\mathrm{a} \quad$ = jumlah tanaman yang bergejala

$\mathrm{N}=$ jumlah tanaman yang diamati

3. Keparahan penyakit (KpP) diukur menggunakan rumus Townsend dan Heuberger (1943) sebagai berikut:

$$
\begin{aligned}
\mathrm{KpP}= & \frac{\sum(\mathrm{ni} \times \mathrm{vi})}{\mathrm{Z} \times \mathrm{N}} \times 100 \% \\
\text { keterangan:KpP }= & \text { keparahan penyakit }(\%) \\
\mathrm{ni}= & \text { jumlah tanaman yang terinfeksi } \\
& \text { dalam setiap kategori } \\
\mathrm{vi}= & \text { nilai numerik masing-masing } \\
& \text { kategori } \\
\mathrm{N}= & \text { jumlah seluruh tanaman yang } \\
& \text { diamati } \\
\mathrm{Z}= & \text { nilai numerik kategori serangan } \\
& \text { tertinggi }
\end{aligned}
$$

\begin{tabular}{|c|c|}
\hline $\begin{array}{c}\text { Nilai } \\
\text { Numerik }\end{array}$ & Keterangan Keparahan Penyakit \\
\hline 0 & Sehat (tidak ada gejala infeksi) \\
\hline 1 & $\begin{array}{l}\leq 25 \% \text { bagian tanaman mengalami } \\
\text { nekrosis }\end{array}$ \\
\hline 2 & $\begin{array}{l}25.1-50 \% \text { bagian tanaman } \\
\text { mengalami nekrosis }\end{array}$ \\
\hline 3 & $\begin{array}{l}>50 \% \text { bagian tanaman mengalami } \\
\text { nekrosis }\end{array}$ \\
\hline 4 & Tanaman mati \\
\hline
\end{tabular}

Nilai numerik merupakan nilai yang diberikan untuk menghitung tingkat keparahan penyakit pada tiap kategori keparahan penyakit. Nilai numerik keparahan bibit jabon yang telah digunakan menurut Aisah (2014) disajikan pada Tabel 1 .

Percobaan dilakukan dengan menggunakan rancangan acak lengkap (RAL) sebanyak tiga ulangan, dan masing-masing ulangan terdiri dari 10 bibit.

Tabel 1 Nilai numerik dan keparahan penyakit mati pucuk bibit jabon (A. cadamba)

Tabel 2 Pengujian in vitro isolat cendawan endofit terhadap B. theobromae pada media ADK

\begin{tabular}{ccc}
\hline $\begin{array}{c}\text { Kode isolat } \\
\text { cendawan } \\
\text { endofit }\end{array}$ & $\begin{array}{c}\text { Persentase } \\
\text { penghambatan } \\
(\%)\end{array}$ & $\begin{array}{c}\text { Kategori } \\
\text { penghambatan }\end{array}$ \\
\hline bnh1.1 & 44.07 & - \\
bnh1.2 & 38.15 & - \\
bnh1.3 & 52.22 & - \\
bnh4.2 & 50.00 & - \\
bnh4.5 & 28.52 & - \\
bnh3.3 & 32.96 & - \\
bnh3.4 & 40.47 & - \\
Kontrol & 00.00 & \\
\hline
\end{tabular}

Keterangan:

$+\quad=$ Terdapat zona penghambatan

- = Tidak ada zona penghambatan
Parameter yang diamati adalah indeks penekanan penyakit dan tingkat kejadian penyakit. Data yang diperoleh dianalisis secara statistik dengan uji lanjut Duncan's New Multiple Range Test (DNMRT) pada taraf 5\%.

\section{HASIL DAN PEMBAHASAN}

\section{Uji In Vitro cendawan endofit terhadap cendawan patogen}

Uji in vitro cendawan endofit terhadap cendawan patogen dilakukan untuk mengetahui persentase penghambatan dan mekanime penghambatan cendawan endofit binahong terhadap cendawan patogen $B$. theobromae penyebab mati pucuk pada jabon. Tabel 2 menunjukkan semua cendawan endofit ( 7 isolat) mampu menghambat perkembangan koloni patogen $B$. theobromae dengan besar nilai hambatan berkisar $28.52 \%$ - 52.22\%. Cendawan endofit bnh1.3 menunjukkan persentase penghambatan tertinggi sebesar $52.2 \%$, diikuti oleh endofit bnh 4.2 sebesar $50 \%$.

Tabel 3 Pengaruh cendawan endofit terhadap masa inkubasi penyakit $B$. theobromae pada bibit jabon putih (A. cadamba)

\begin{tabular}{lccccccc}
\hline Perlakuan & \multicolumn{7}{c}{ Hari setelah inokulasi } \\
\cline { 2 - 7 } & 1 & 2 & 3 & 4 & 5 & 6 & 7 \\
\hline bnh1.1 & + & + & + & + & + & + & + \\
bnh1.2 & + & + & + & + & + & + & + \\
bnh1.3 & + & + & + & + & + & + & + \\
bnh4.2 & - & - & + & + & + & + & + \\
bnh4.5 & - & - & + & + & + & + & + \\
bnh3.3 & + & + & + & + & + & + & + \\
bnh3.4 & + & + & + & + & + & + & + \\
Kontrol & + & + & + & + & + & + & + \\
\hline
\end{tabular}

Keterangan:

$+=$ Timbul gejala penyakit

- $\quad=$ Tidak terbentuk gejala penyakit

Tabel 4 Pengaruh cendawan endofit terhadap besar kejadian dan keparahan penyakit $B$. theobromae pada bibit jabon putih ( $A$. cadamba)

\begin{tabular}{cccc}
\hline Perlakuan & $\begin{array}{c}\text { Kejadian } \\
\text { penyakit } \\
(\%)\end{array}$ & $\begin{array}{c}\text { Keparahan } \\
\text { penyakit } \\
(\%)\end{array}$ & $\begin{array}{c}\text { Tingkat } \\
\text { penekanan } \\
\text { penyakit } \\
\text { relatif }(\%)\end{array}$ \\
\hline bnh1.1 & 100 & $75.00 \mathrm{~b}$ & 9.17 \\
bnh1.2 & 100 & $59.20 \mathrm{~d}$ & 24.94 \\
& & & \\
bnh1.3 & 100 & $58.33 \mathrm{~d}$ & 25.84 \\
bnh4.2 & 100 & $43.33 \mathrm{f}$ & 40.84 \\
bnh4.5 & 100 & $50.83 \mathrm{e}$ & 33.34 \\
& & & \\
bnh3.3 & 100 & $70.83 \mathrm{bc}$ & 13.34 \\
bnh3.4 & 100 & $64.17 \mathrm{~cd}$ & 20.00 \\
Kontrol & 100 & $84.17 \mathrm{a}$ & \\
\hline
\end{tabular}

Keterangan: Angka yang diikuti huruf yang berbeda menyatakan berbeda nyata pada selang kepercayaan 95\% berdasarkan uji Duncan 
Pertumbuhan cendawan patogen $B$. theobromae terhambat oleh cendawan endofit tetapi tidak terbentuk zona hambatan antar kedua koloni. Hal ini menujukkan kemampuan cendawan endofit dalam menghambat pertumbuhan patogen $B$. theobromae bukan melalui mekanisme antibiosis. Tidak terbentuknya zona hambatan yang berupa zona bening pada uji ini menunjukkan bahwa cendawan endofit tersebut tidak mampu mengeluarkan senyawa antibiotik. Mekanisme pengendalian dengan agen hayati terhadap jamur patogen tumbuhan secara umum dibagi menjadi tiga macam, yaitu kompetisi terhadap tempat tumbuh dan nutrisi, antibiosis, dan parasitisme (Baker dan Cook 1982). Tertekannya pertumbuhan fungi patogen menunjukkan mekanisme kompetisi dalam antagonisme. Dalam hal ini cendawan endofit lebih kompetitif dalam memanfaatkan ruang tumbuh dan nutrisi. Lebih kompetitifnya fungi antagonis ditunjang oleh pertumbuhannya yang lebih cepat dibanding fungi patogen pada media yang sama. Umumnya kematian mikroorganisme disebabkan kekurangan nutrisi, oleh karena itu salah satu tujuan pengendalian patogen dengan agen hayati adalah untuk memenangkan kompetisi dalam mendapatkan nutrisi (Berlian et al. 2013).

\section{Seleksi Potensi Cendawan Endofit secara In Vivo}

\section{Masa Inkubasi}

Masa inkubasi adalah waktu setelah inokulasi patogen $B$. theobromae sampai terlihatnya gejala penyakit, yang secara visual berupa bercak nekrosis berwarna coklat. Berdasarkan hasil penelitian (Tabel 3), bibit jabon putih (A. cadamba) yang mendapatkan perlakuan cendawan endofit bnh1.1, bnh1.2, bnh1.3, bnh3.3, dan bnh3.4 serta mendapatkan infeksi dari $B$. theobromae menunjukkan gejala penyakit mulai pada hari pertama setelah inokulasi. Bibit jabon dinyatakan terinfeksi jika ditemukan bercak coklat pada batang bibit yang diinokulasi. Perlakuan isolat bnh 4.5 dan bnh4.2 memiliki masa inkubasi lebih lama dibandingkan perlakuan lainnya (1 HSI), yaitu gejala penyakit pada kedua perlakuan isolat tersebut mulai muncul pada hari ke-3 HSI. Menurut Yanti et al. (2015), bahwa gejala penyakit pada bibit jabon putih dengan cara infeksi tanpa maupun dengan pelukaan batang tampak pada 1 hari setelah inkubasi (HSI). Reaksi ketahanan antara lain ditunjukkan dengan tertundanya gejala penyakit tanaman. Hal ini menunjukkan perlakuan isolat bnh4.5 dan bnh4.2 mampu menginduksi ketahanan jabon terhadap penyakit mati pucuk yang disebabkan $B$. theobromae.

\section{Kejadian dan Keparahan Penyakit Mati Pucuk}

Hasil uji in vivo pada Tabel 4 menunjukkan bahwa pemberian cendawan endofit dan perlakuan $B$. theobromae dengan cara pelukaan belum mampu menghambat kejadian penyakit mati pucuk pada bibit jabon putih (A. cadamba). Kejadian penyakit pada semua perlakuan cendawan endofit adalah sebesar $100 \%$, sedangkan pada kontrol yang tidak diberi perlakuan patogen tidak muncul gejala penyakit.
Penelitian ini menggunakan isolat $B$. theobromae yang virulen dengan metode inokulasi patogen yakni pelukaan dengan jarum suntik. Metode tersebut sangat membantu proses penetrasi dan mempercepat proses infeksi B. theobromae pada tanaman jabon. Menurut Arshinta (2013), bahwa bibit jabon putih yang diinokulasi patogen, baik berumur 3, 4, dan 5 bulan menunjukkan mati pucuk, namun pada bibit jabon putih tanpa inokulasi patogen tidak menunjukkan gejala mati pucuk.

Parameter tingkat keparahan penyakit menunjukkan nilai yang berbeda nyata dengan kontrol. Tingkat keparahan penyakit tertinggi terjadi pada bibit jabon putih (A. cadamba) yang tidak diberi perlakuan cendawan endofit (perlakuan kontrol) yaitu sebesar $84.17 \%$. Berdasarkan Tabel 4, perlakuan pemberian cendawan endofit bnh4.5 dan bnh4.2 lebih mampu menekan perkembangan patogen dengan persentase penekanan penyakit relatif masing-masing sebesar $33.34 \%$ dan $40.84 \%$. Hasil ini sesuai dengan pengamatan masa inkubasi penyakit pada bibit jabon yang diberi perlakuan cendawan endofit bnh4.5 dan bnh4.2 menunjukkan masa inkubasi yang lebih lama dibanding perlakuan cendawan endofit lainnya. Mekanisme cendawan endofit dalam menekan serangan B.theobromae pada bibit jabon (A. cadamba) diduga juga melalui mekanisme ketahanan terinduksi. Mekanisme ketahanan terinduksi terjadi ketika adanya peningkatan ketahanan pada tanaman inang terhadap infeksi patogen setelah diberi stimulan (Taufik et al. 2010).

\section{SIMPULAN}

Hasil uji in vitro menunjukkan bahwa semua cendawan endofit ( 7 isolat) mampu menghambat perkembangan koloni patogen $B$. theobromae penyebab penyakit mati pucuk pada jabon putih (A. cadamba) dengan besar nilai hambatan berkisar $28.52 \%-52.22 \%$. Perlakuan dengan menggunakan cendawan endofit bnh4.5 dan bnh4.2 pada bibit jabon juga dapat meningkatkan ketahanan jabon terhadap B. theobromae, yang ditunjukkan dengan tertundanya masa inkubasi (2 HSI) dan menurunnya keparahan penyakit masingmasing sebesar $33.34 \%$ dan $40.84 \%$. Hal ini menunjukkan cendawan endofit binahong mempunyai peluang sebagai agensia pengendalian hayati pada jabon.

\section{DAFTAR PUSTAKA}

Anggraeni I, Lelana NI. 2011. Diagnosis Penyakit Tanaman Hutan. Haneda NF, Rahayu S, editor. Bogor (ID): Pusat Litbang Peningkatan Produktivitas Hutan.

Aisah AR. 2014. Identifikasi dan Patogenitas Cendawan Penyebab Primer Penyakit Mati Pucuk pada Bibit Jabon (Anthocephalus cadamba (Roxb.) Miq). [tesis]. Bogor: Institut Pertanian Bogor.

Arshinta P. 2013. Pengaruh pH dan Penggoyangan Media terhadap Pertumbuhan Botryodiplodia sp. 
dan Uji Patogenisitas Botryodiplodia sp. pada Bibit Jabon [skripsi]. Bogor: Institut Pertanian Bogor.

Baker KF, RJ Cook. 1982. Biological control of plant pathogens. The American Phytopathology Society. Minnessota Fravel.

Begoude BAD, Bernard S, Michael JW, Jolanda R. 2009. Botryosphaeriaceae Associated with Terminalia Cattapa in Cameroon, South Africa and Madagascar. Mycol Progress 9: 101-123.

Berlian I, Setyawan B, Hadi H. 2013. Mekanisme antagonisme spp. terhadap beberapa patogen tular tanah. Warta Perkaretan. 32(2):74-82.

Berlian I, Setyawan B, Hadi H. 2013. Mekanisme antagonisme $\mathrm{T}$ richoderma spp. terhadap beberapa patogen tular tanah. Warta Perkaretan, 32(2), 7482.

Clay K. 1988. Fungal Endophytes of Grasses: a Defensive Mutualism between Plants and Fungi. Ecology 69: 1-16.

Darsana IGO, Besung INK, Mahatmi H. 2012. Potensi daun binahong (Anredera cordifolia (Tenore) Steenis) dalam menghambat pertumbuhan bakteri Escherichia coli secara in vitro. Indonesia Medicus Veterinus. 1(3): 337-351.

Faeth SH. 2002. Are endophytic fungi defensive plant mutualists?. Oikos 98: 25-36.

Halawane JE, Hanif NH, Kinho J. 2011. Prospek Pengembangan Jabon Merah (Anthocephalus macrophyllus (Roxb.) Havil), Solusi Kebutuhan Kayu Masa Depan. Manado (ID): Badan Penelitian dan Pengembangan Kehutanan.

Herliyana EN, Achmad, Putra A. 2012. Pengaruh Pupuk Organik Cair terhadap Pertumbuhan bibit Jabon (Anthocephalus cadamba Miq.) dan Ketahanannya terhadap Penyakit. Jurnal Silvikultur Tropika. 03(03): 168-173.

Mulyana D, Asmarahman C, Fahmi I. 2010. Bertanam Jabon. Jakarta (ID): Agromedia Pustaka.

Niere B. 2002. Banana Endophyte: Potential for Pest Biocontrol. IITA-ESARC. Kampala, Uganda.

Oka S. 1962. Mechanism of Antimicrobial Effect of Quinone Compounds. Journal Agricultural and
Biological Chemistry. 26(08):500-514. https://www.tandfonline.com/doi/abs/10.1080/000 21369.1962.10858008.

Orwa C, Mutua A, Kindt R, Jamnadass R, Anthony S. 2009. Agroforestry tree database: a tree species reference and selection guide version 4.0. www.wordagroforestry.org/treedb2/AFTPDFS/Ant hocephalus cadamba.pdf

Semangun H. 2007. Penyakit-Penyakit Tanaman Hortikultura di Indonesia. Ed ke-2. Yogyakarta (ID): Gadjah Mada University Pr.

Singh S, Nag SK, Kundu SS, Maity SB. 2010. Relative intake, eating pattern, nutrient digestibility, nitrogen metabolism, fermentation pattern and growth performance of lambs fed organically and inorganically produced cowpea hay-barley grain diets. Trop. Grassl. 44:55-61.

Sinclair JB, Cerkauskas RF. 1996. Latent Infection vs. Endophytic Colonization by Fungi. Di dalam : Redlin SC, Carris LM. Endophytic Fungi in Grasses and Woody Plants: Systematics, Ecology and Evolution. Aps. Press The American Phytopathological Society St. Paul. Minnesota. 2329.

Tan RX, Zou WX. 2001. Endophytes: a rich source of functional metabolites. Nat.Prod. Rep. 18:448-459.

Taufik M, Rahman A, Wahab A, Hidayat SH. 2010. Mekanisme ketahanan terinduksi oleh plant growth promotting Rhizobacteria (PGRP) pada tanaman cabai terinfeksi cucumber mosaik virus (CMV). Jurnal Hortikultura. 20(3).

Townsend GR, Heuberger JW. 1943. Methods for estimating losses caused by diseases in fungicides experiments. Plant Disease Reporter. 27: 340-343.

Wahyudi. 2012. Analisis Pertumbuhan dan Hasil Tanaman Jabon (Anthocephalus cadamba). J Pertanian 8(1):19-24.

Warisno, Dahana K. 2011. Peluang Investasi: J Tanaman Kayu Masa Depan. Jakarta (ID): Gramedia Pustaka Utama. 